\title{
PENGARUH KEGIATAN EKSTRAKURIKULER KELOMPOK ILMIAH REMAJA TERHADAP KETERAMPILAN MENULIS KARYA ILMIAH SISWA KELAS XI SMA NEGERI 1 SAWAN
}

\author{
P. Herlyn Novita Dewi ${ }^{1}$, Sang Ayu P. Sriasih ${ }^{2}$, I N. Sudiana ${ }^{3}$ \\ Jurusan Pendidikan Bahasa dan Sastra Indonesia \\ Universitas Pendidikan Ganesha \\ Singaraja, Indonesia \\ e-mail: \{putu.herlinnovitadewi@yahoo.com, sap.sriasih@yahoo.com, \\ sudiana195723@gmail.com\}
}

\begin{abstract}
ABSTRAK
Penelitian ini bertujuan untuk mengetahui (1) pengaruh kegiatan ekstrakurikuler Kelompok IImiah Remaja terhadap keterampilan menulis karya ilmiah siswa kelas XI SMA Negeri 1 Sawan (2) kualitas karya ilmiah yang dihasilkan oleh siswa kelas XI anggota Kelomok IImiah Remaja dengan yang bukan anggota Kelomok IImiah Remaja. Penelitian ini menggunakan rancangan penelitian Ex Post Facto. Populasi penelitian ini adalah seluruh siswa kelas XI SMA Negeri 1 Sawan tahun ajaran 2017/2018. Sampel pada penelitian ini adalah 30 siswa yang menjadi anggota KIR, dan 30 siswa yang bukan anggota KIR. Metode pengumpulan data yang digunakan adalah metode dokumentasi. Data dikumpulkan telah dianalisis menggunakan metode analisis data statistik dengan menggunakan teknik uji $\mathrm{T}$ dan dianalisis secara deskriptif kuantitatif. Hasil penelitian ini adalah (1) terdapat pengaruh kegiatan ekstrakurikuler KIR terhadap keterampilan menulis karya ilmiah siswa kelas XI SMA Negeri 1 Sawan. Hal ini ditunjukkan pada nilai thitung $>$ tabel $(6,907>2,001)$ dan nilai signifikan $0,000<0,05$ yang berarti $\mathrm{H}_{0}$ ditolak. (2) Terdapat perbedaan kualitas karya ilmiah yang dihasilkan oleh siswa anggota KIR dengan siswa yang bukan anggota KIR. Hal ini bisa dilihat dari rata-rata nilai siswa anggota KIR 79,27 sedangkan rata-rata nilai siswa bukan anggota KIR 70,30. Saran dalam penelitian ini (1) siswa diharapkan lebih mudah termotivasi untuk mengikuti kegiatan ekstrakurikuler KIR, (2) guru diharapkan mampu mendorong motivasi siswa untuk mengikuti kegiatan ekstrakurikuler KIR, (3) bagi sekolah hasi penelitian ini diharapkan kepada kepala sekolah mampu menggunakan ini sebagai dasar untuk meningkatkan penulisan karya ilmiah melalui kegiatan ekstrakurikuler KIR.
\end{abstract}

Kata kunci: ekstrakurikuler KIR, keterampilan menulis, karya ilmiah

This study aims to determine (1) the influence of extracurricular activities of Youth Scientific Club on the scientific writing skills of grade XI students of SMA Negeri 1 Sawan (2) the quality of scientific work produced by the XI class students of the Youth Scientific Club with non-members of the Youth Scientific Club. This study used Ex Post Facto research design. The population of this study is all students of class XI SMA Negeri 1 Sawan academic year 2017/2018. The sample of this study is 30 students who are the members of YSC, and 30 students who are not the members of YSC. The method of data collection uses documentation method. The data collected is analyzed using T-test technique and analyzed descriptively quantitatively. The results of this research are (1) there is influence of KIR extracurricular activity to the writing skill of the students of grade XI of SMA Negeri 1 Sawan. This is shown by the value of tcount $>$ ttable $(6,907>2,001)$ and significant value $0,000<0,05$ meaning $\mathrm{H} 0$ is rejected. (2) There is a difference in the quality of scientific work produced by the YSC students compare to the students who are not members of YSC. This can be seen from the students' average scores of YSC members is 79.27 while the student's average score who are not a member of YSC is 70.30 . There 
are some suggestions can be a consideration in this study, such as (1) students are expected to be more motivated to follow extracurricular activities of YSC, (2) teachers are expected to encourage students' motivation to follow extracurricular activities of YSC, (3) for the school, it is expected to principal to be able to use this as a basis to improve the scientific writing papers through YSC extracurricular activities.

Keywords: YSC extracurricular, writing skill, scientific papers

\section{PENDAHULUAN}

Dalam pembelajaran bahasa Indonesia, ada empat keterampilan berbahasa yaitu keterampilan menyimak, berbicara, membaca, dan menulis. Keempat aspek tersebut sama-sama penting, tidak ada aspek keterampilan yang tidak penting. Dari keempat keterampilan berbahasa tersebut, menulis merupakan kegiatan yang sangat penting untuk dikuasai. Dikatakan sangat penting karena menulis merupakan bagian yang tidak terpisahkan dari proses pembelajaran yang dialami siswa selama menuntut ilmu, baik itu tingkat SD, SMP, maupun SMA, bahkan sampai ke perguruan tinggi. Keberhasilan siswa dalam mengikuti pembelajaran di sekolah banyak ditentukan oleh keterampilan menulis. Selain dapat menjadikan siswa berpikir kritis, menulis juga dapat digunakan untuk mengungkapkan ide, gagasan, perasaan, serta pengalaman kepada orang lain.

Suandi, dkk. (2013:

mengungkapkan menulis merupakan serangkaian kegiatan seseorang mengungkapkan gagasan dan menyampaikan informasi melalui bahasa tulis kepada masyarakat pembaca untuk dipahami. Dengan keterampilan menulis seseorang akan dapat melaporkan, memberitahukan, dan meyakinkan orang lain. Pendapat berbeda dikemukakan oleh Keraf (2007:52), bahwa menulis adalah suatu kegiatan yang produktif dan ekspensif. Dengan demikian, menulis merupakan hal yang sangat penting yang perlu dikuasai oleh seseorang.

Salah satu keterampilan menulis yang harus dikuasai oleh kaum intelektual adalah menulis karya ilmiah. Pada dasarnya kurikulum bahasa Indonesia sudah mencakup seluruh keterampilan berbahasa, termasuk menulis. Kurikulum tersebut dijabarkan dalam Standar Kompetensi dan
Kompetensi Dasar dari jenjang SD sampai SMA. Salah satu Kompetensi Dasar (SK) yang ada dalam kurikulum bahasa Indonesia adalah menulis karya ilmiah yang diberikan di jenjang SMA.

Karya ilmiah adalah hasil atau produk manusia yang biasanya dalam bentuk tulisan atas dasar pengetahuan, sikap, dan cara berpikir ilmiah (Wendra, 2016:2). Itu berarti sudah tentu setiap karya ilmiah harus mengandung kebenaran ilmiah. Kebenaran ilmiah yang dimaksud yakni kebenaran yang tidak hanya didasarkan atas rasio, tetapi juga dibuktikan secara empiris. Menulis karya ilmiah berbeda dengan mengarang biasa. Menulis karya ilmiah membutuhkan metode dan teknik tulisan tertentu sehingga hasil tulisan dapat dipertanggungjawabkan kebenarannya. Oleh karena itu, tidak semua orang terampil menulis karya ilmiah. Namun, tuntutan pendidikan zaman yang kompetitif seperti saat ini sangat membutuhkan keteramppilan menulis karya ilmiah untuk memecahkan berbagai persoalan dengan tepat. Orang yang terampil menulis karya ilmiah akan memiliki nilai lebih dibandingkan dengan orang yang tidak menulis karya ilmiah. nilai lebih yang dimaksud adalah orang yang terampil menulis karya ilmiah mereka akan kaya ilmu pengetahuan, wawasan, bahkan finansial. Mereka terbiasa berpikir sistematis, cermat, tidak sembarangan dalam mengidentifikasi dan memecahkan persoalan.

Keterampilan menulis karya ilmiah tidak hanya bisa didapatkan di dalam kelas atau melalui proses pembelajaran di dalam kelas saja. Namun, keterampilan tersebut bisa didapatkan di luar jam pelajaran. Keterampilan tersebut bisa didapatkan dalam kegiatan ekstrakurikuler. Kegiatan ekstrakurikuler merupakan kegiatan yang dilakukan di luar kelas dan di luar jam 
pelajaran untuk menumbuhkembangkan potensi sumber daya manusia (SDM) yang dimiliki peserta didik, baik berkaitan dengan aplikasi ilmu pengetahuan yang didapatkan maupun dalam pengertian khusus untuk membina peserta didik dalam mengembangkan potensi dan bakat yang ada dalam dirinya melalui kegiatan-kegiatan wajib maupun pilihan. Anwar (2015:47) mengungkapkan ekstrakurikuler merupakan rancangan atau usaha yang dijalankan dalam bentuk kegiatan yang dilakukan di luar jam pelajaran tatap muka, baik dilaksanakan di sekolah maupun di luar sekolah dengan tujuan untuk memperluas wawasan pengetahuan dan kemampuan yang telah dipelajari siswa dalam bidang studi.

Salah satu kegiatan ekstrakurikuler yang dapat menambah ilmu pengetahun di bidang menulis karya ilmiah adalah ekstrakurikuler KIR. KIR adalah kelompok remaja yang melakukan serangkaian kegiatan yang menghasilkan karya ilmiah (Susilowarno, 2003:1). Dari pengertian tersebut sudah sangat jelas bahwa keterampilan menulis karya ilmiah tidak hanya bisa didapatkan pada jam pelajaran saja, namun pada kegiatan ekstrakurikuler KIR pun bisa diperoleh ilmu tentang penulisan karya ilmiah. Kegiatan menulis karya ilmiah merupakan suatu kegiatan yang oleh sebagian remaja dianggap sulit, sebab menulis karya ilmiah harus dengan berpikir ilmiah dan harus mengandung kebenaran ilmiah. Hal ini berbeda dengan menulis karya-karya yang lain seperti cerpen dan sejenisnya yang lebih memerhatikan keindahan. Walupun kegiatan menulis karya ilmiah oleh sebagian besar dianggap sulit, bukan berarti tidak dapat dipelajari.

Kegiatan ekstrakurikuler KIR merupakan salah satu kegiatan yang bersifat terbuka bagi remaja sebagai peserta didik yang ingin mengembangkan kreativitas, ilmu pengetahun, dan teknologi (IPTEK) dan bertujuan agar mampu menanamkan sikap ilmiah, kejujuran dalam memecahkan masalah yang ditemui dengan kepekaan tinggi serta menggunakan metode yang sistematis, objektif, rasional dan berprosedur sehingga akan didapatkan kompetensi untuk mengembangkan diri dalam kehidupan masa kini atau mendatang (Susilowarno 2003:2).

Pada saat ini, hampir seluruh sekolah mempunyai atau menerapkan kegiatan ekstrakurikuler KIR dengan harapan yang sama agar siswa mendapatkan ilmu pengetahuan yang lebih. SMA Negeri 1 Sawan merupakan salah satu SMA yang memiliki kegiatan ekstrakurikuler KIR. Guru pembina kegiatan ekstarkurikuler KIR SMA Negeri 1 Sawan mengatakan bahwa SMA Negeri 1 Sawan memiliki ekstrakurikuler KIR yang terbuka lebar untuk seluruh siswa di SMA Negeri 1 Sawan tidak terkecuali. Namun, pada kenyataannya kegiatan eksrtakurikuler KIR kurang diminati dan kurang diikuti oleh siswa dibandingkan dengan kegiatan ekstrakurikuler lain. Hal ini dapat dilihat dari jumlah siswa di SMA Negeri 1 Sawan dari kelas $X$ hingga kelas XII yaitu 685 siswa sedangkan yang mengikuti ekstrakurikuler Kelompok IImiah Remaja kurang lebih 30 siswa. Siswa beranggapan bahwa kegiatan tersebut hanya diikuti oleh siswa yang pintar dan siswa yang memiliki prestasi. Oleh karena itu, kegiatan ekstrakurikuler KIR di SMA Negeri 1 Sawan hanya diikuti oleh siswa yang memiliki minat tinggi untuk belajar dan memperoleh pengalaman organisasi.

Siswa yang mengikuti kegiatan ekstrakurikuler KIR sudah tentu akan memilki wawasan yang lebih luas dibandingkan dengan siswa yang tidak mengikuti kegiatan ektarakurikuler KIR. Siswa yang mengikuti kegiatan esktarkurikuler KIR akan diberikan ilmu pengetahuan, keterampilan dan ilmu yang lain dari guru pembina KIR sehingga siswa memiliki pengalaman langsung baik pada pembelajaran di kelas maupun pada pembelajaran di luar kelas (ekstrakurikuler $\mathrm{KIR}$ ). Siswa yang tidak mengikuti kegiatan ekstrakurikuler KIR hanya mendapatkan pengetahuan terbatas pada pembelajaran di dalam kelas saja, sehingga mereka kurang memiliki pengetahuan yang luas dan keterampilan yang cukup. Siswa yang mengikuti kegiatan ekstrakurikuler KIR di SMA Negeri 1 Sawan sebagian besar berasal dari siswa kelas XI saja. Padahal, 
ekstrakurikuler KIR ini sangat penting dan sangat baik untuk diikuti mengingat perkembangan yang ada untuk memenuhi syarat-syarat tertentu seseorang harus bisa menulis. Bahkan di perguruan tinggi pun mahasiswa diwajibkan bisa menulis karya ilmiah.

Berdasarkan pengetahuan peneliti, masalah mengenai pengaruh kegiatan ekstrakurikuler KIR terhadap keterampilan menulis karya ilmiah belum pernah diteliti sebelumnya. Akan tetapi, penelitian serupa pernah dilakukan oleh Kristina Riawati pada tahun 2017 dengan judul "Pengaruh Model Pembelajaran Kontekstual terhadap Keterampilan Menulis Karya IImiah Ditinjau dari Kemampuan Bernalar (Eksperimen pada Siswa Kelas XI SMK Negeri Kabupaten Sragen)". Penelitian serupa yang kedua dilakukan oleh Pungky Septiriani pada tahun 2017 dengan judul "Korelasi Kegiatan Ekstrakurikuler Kelompok IImiah Remaja (KIR) dengan Kemampuan Literasi Informasi Siswa SMA Negeri 2 Malang". Penelitian serupa yang ketiga dilakukan oleh Pasmiati pada tahun 2011, dengan judul "Peningkatan Keterampilan Menulis Karya Tulis IImiah melalui Model Pembelajaran Berbasis Masalah Berbantuan lemabar Kerja Siswa Pada Siswa Kelas XI IPA 2 SMA Negeri 1 Ungaran" Ketiga penelitian tersebut memang sejenis, namun penelitian tersebut tentu berbeda dengan penelitian yang peneliti lakukan. Terutama pada populasi dan sampel penelitian, serta rancangan penelitian yang digunakan.

Berdasarkan uraian yang telah dipaparkan, perlu dilakukan suatu penelitian pada kegiatan ekstrakurikuler KIR di SMA Negeri 1 Sawan terhadap keterampilan menulis karya ilmiah. Penelitian ini dilakukan untuk mengetahui apakah kegiatan ekstrakurikuler kelompok ilmiah remaja berpengaruh terhadap keterampilan menulis karya ilmiah, serta bagaimanakah kualitas karya ilmiah yang dihasilkan oleh siswa anggota KIR dan siswa bukan anggota KIR. Dengan demikian, penelitian ini bertujuan untuk 1) mengetahui pengaruh kegiatan ekstrakurikuler KIR terhadap keterampilan menulis karya ilmiah siswa kelas XI SMA Negeri 1 Sawan, 2) mengetahui kualitas karya ilmiah yang dihasilkan oleh siswa anggota KIR dengan siswa yang bukan anggota KIR.

\section{METODE PENELITIAN}

Penelitian ini dilakukan di SMA Negeri 1 Sawan yang beralamat di Desa Sangsit, Banjar Abasan. Sedangkan penelitian dilaksanakan pada bulan Maret sampai April 2018. Rancangan penelitian yang digunakan adalah Ex Post Facto atau sering disebut dengan penelitian kausal komparatif. Alasan peneliti menggunakan rancangan penelitian tersebut, karena variabel bebas dalam penelitian ini tidak dikendalikan atau diperlakukan khusus melainkan hanya mengungkap fakta berdasarkan pengukuran gejala yang telah ada pada diri responden sebelum penelitian ini dilaksanakan. Hal ini, sesuai dengan pendapat yang dikemukakan Sugiyono (2010:165) bahwa penelitian Ex Post Facto adalah suatu penelitian yang dilakukan untuk meneliti peristiwa yang telah terjadi dan kemudian menurun ke belakang untuk mengetahui faktor-faktor yang dapat menyebabkan timbulnya kejadian tersebut. Dalam penelitian ini, peneliti menggunakan desain penelitian The Basic Causal Comparative Desain, atau dengan kata lain peneliti menitikberatkan pada penelitian komparatif. Pada desain ini sampel dibagi menjadi dua kelompok yakni kelompok yang mengikuti ekstrakurikuler KIR dan kelompok yang tidak mengikuti ekstrakurikuler KIR. Untuk memperjelas tentang desain penelitian The Basic Causal Comparative Desain yang dimaksud dapat dilihat pada gambar berikut:

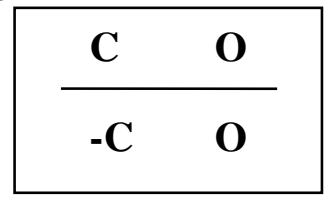

Populasi pada penelitian ini adalah seluruh siswa kelas XI SMA Negeri 1 Sawan tahun ajaran 2017/2018. Sampel dalam penelitian ini adalah 30 siswa yang menjadi anggota KIR, dan 30 siswa yang bukan menjadi anggota KIR di SMA Negeri 1 Sawan. Pengambilan sampel dilakukan 
dengan teknik purosive sampling, yaitu teknik pengambilan sampel dengan tidak berdasarkan random melainkan berdasarkan adanya pertimbangan yang berfokus pada tujuan tertentu.

Metode pengumpulan data merupakan salah satu faktor penting untuk memecahkan masalah suatu penelitian. Maka dari itu, penggunaan metode pengumpulan data merupakan cara yang harus ditempuh dan dilakukan oleh peneliti dalam melakukan sebuah penelitian guna memperoleh data tentang penelitian. Berkaitan dengan metode pengumpulan data, dalam penelitian ini metode pengumpulan data yang digunakan yaitu, metode dokumentasi. Sugiyono (dalam Gunawan, 2015:178) berpendapat bahwa metode dokumentasi adalah metode yang berbentuk tulisan, gambar, dan karya. Metode dokumentasi digunakan dalam penelitian ini untuk mengumpulkan data berupa hasil tes tulisan karya ilmiah yang dibuat oleh siswa yan mengikuti kegiatan ekstrakurikuler KIR dengan siswa yang tidak mengikuti kegiatan ekstrakurikuler KIR. Metode dokumentasi ini digunakan oleh peneliti, karena tes keterampilan menulis karya ilmiah sudah dilakukan oleh guru baik untuk siswa yang mengikuti kegiatan ekstrakurikuler KIR dan siswa yang tidak mengikuti kegiatan ekstrakurikuler KIR, sehingga peneliti hanya mengambil hasil tulisan karya ilmiah yang sudah ada dari siswa yang tidak mengikuti kegiatan ekstrakurikuler KIR dan siswa yang mengikuti kegiatan ekstrakurikuler KIR. Metode dokumentasi ini didukung dengan indikator penilaian penulisan karya ilmiah berupa makalah.

Setelah data semua terkumpul, langkah selanjutnya yaitu analisis data. Analisis data yang digunakan pada penelitian ini yaitu pada rumusan masalah yang pertama menggunakan metode analisis data statistik dengan menggunakan teknik uji $\mathrm{T}$ dan untuk rumusan masalah yang kedua menggunakan teknik analisis data deskriptif kuantitatif. Adapun langkahlangkah yang ditempuh yaitu (1) uji normalitas data, (2) uji homogenitas data, (3) uji hipotesis data.

\section{HASIL DAN PEMBAHASAN}

Data yang diperoleh dalam penelitian ini dikelompokkan menjadi dua yaitu, (1) hasil nilai karya ilmiah siswa yang menjadi anggota KIR (2) hasil nilai siswa yang bukan anggota KIR. Data nilai yang diperoleh dari siswa anggota KIR dan siswa yang bukan anggota KIR dapat dilihat pada tabel 1 dan 2.

Tabel 1

Nilai Karya Ilmiah Siswa Anggota KIR

\begin{tabular}{|c|c|c|}
\hline No & Nama & $\begin{array}{lr}\text { Nilai } & \text { Karya } \\
\text { Ilmiah } & \text { Siswa } \\
\text { yang } & \text { Mengikuti } \\
\text { Ekstrakurikuler } \\
\text { KIR } \quad \text { (anggota } \\
\text { KIR) }\end{array}$ \\
\hline 1 & $\begin{array}{l}\text { Kadek } \\
\text { Mertada }\end{array}$ & 88 \\
\hline 2 & $\begin{array}{l}\text { Kadek } \\
\text { Redita }\end{array}$ & 79 \\
\hline 3 & $\begin{array}{l}\text { Kadek } \\
\text { Sinta } \\
\text { Sriantini }\end{array}$ & 80 \\
\hline 4 & $\begin{array}{l}\text { Kadek } \\
\text { Yenik } \\
\text { Fransiska }\end{array}$ & 78 \\
\hline 5 & $\begin{array}{l}\text { Kadek Ardi } \\
\text { Santika }\end{array}$ & 77 \\
\hline 6 & $\begin{array}{l}\text { Kadek Ayu } \\
\text { Diah } \\
\text { Lestari }\end{array}$ & 76 \\
\hline 7 & $\begin{array}{l}\text { Kadek Puja } \\
\text { Tari }\end{array}$ & 78 \\
\hline 8 & $\begin{array}{l}\text { Kadek } \\
\text { Mudiani }\end{array}$ & 87 \\
\hline 9 & $\begin{array}{l}\text { Kadek Rudi } \\
\text { Maharjaya }\end{array}$ & 77 \\
\hline 10 & $\begin{array}{l}\text { Kadek Rian } \\
\text { Adi } \\
\text { Nugraha }\end{array}$ & 83 \\
\hline 11 & $\begin{array}{l}\text { Kadek } \\
\text { Tiara } \\
\text { Yuliantari }\end{array}$ & 73 \\
\hline 12 & $\begin{array}{l}\text { Kadek } \\
\text { Apriliani }\end{array}$ & 81 \\
\hline 13 & $\begin{array}{l}\text { Putu } \\
\text { Sugiartini }\end{array}$ & 70 \\
\hline 14 & $\begin{array}{l}\text { Putu } \\
\text { Yuliantari }\end{array}$ & 79 \\
\hline 15 & Putu Risma & 81 \\
\hline
\end{tabular}




\begin{tabular}{|c|c|c|}
\hline & Aqustini & \\
\hline 16 & $\begin{array}{l}\text { Putu } \\
\text { Wahyuni }\end{array}$ & 78 \\
\hline 17 & $\begin{array}{lr}\text { Putu } & \text { Tri } \\
\text { Janu } & \text { Budi } \\
\text { Utama } & \end{array}$ & 80 \\
\hline 18 & $\begin{array}{l}\mathrm{Ni} \text { Putu } \\
\text { Dasniari }\end{array}$ & 87 \\
\hline 19 & $\begin{array}{l}\mathrm{Ni} \text { Ketut } \\
\text { Wintariani }\end{array}$ & 78 \\
\hline 20 & $\begin{array}{l}\text { Ni Nyoman } \\
\text { Suantini }\end{array}$ & 80 \\
\hline 21 & $\begin{array}{l}\text { Komang } \\
\text { Kiki Kristina } \\
\text { Dewi }\end{array}$ & 79 \\
\hline 22 & $\begin{array}{l}\text { Komang } \\
\text { Sugiantini }\end{array}$ & 77 \\
\hline 23 & $\begin{array}{l}\text { Komang Sri } \\
\text { Kundulan }\end{array}$ & 74 \\
\hline 24 & $\begin{array}{l}\text { Komang } \\
\text { Lanang } \\
\text { Satya } \\
\text { Yudana }\end{array}$ & 83 \\
\hline 25 & Luh Suardi & 77 \\
\hline 26 & $\begin{array}{l}\text { Gede Doris } \\
\text { Heriawan }\end{array}$ & 87 \\
\hline 27 & $\begin{array}{l}\text { Ketut Ary } \\
\text { Wahyuni }\end{array}$ & 78 \\
\hline 28 & $\begin{array}{l}\text { Made } \\
\text { Suputri } \\
\text { Yani }\end{array}$ & 84 \\
\hline 29 & Ayu Lestari & 78 \\
\hline 30 & $\begin{array}{l}\text { Gusti Ayu } \\
\text { Klaudia } \\
\text { Devi }\end{array}$ & 71 \\
\hline \multicolumn{2}{|c|}{ TotaL } & 2378 \\
\hline
\end{tabular}

Tabel 2

Nilai Karya Ilmiah Siswa Bukan Anggota KIR

\begin{tabular}{|c|c|c|}
\hline No & Nama & $\begin{array}{lr}\text { Nilai } & \text { Karya } \\
\text { Ilmiah } & \text { Siswa } \\
\text { yang } & \text { Tidak } \\
\text { Mengikuti } & \\
\text { Ekstrakurikuler } \\
\text { KIR (bukan } \\
\text { angqota } & \text { KIR) }\end{array}$ \\
\hline 1 & Luh Juli Artini & 79 \\
\hline 2 & $\begin{array}{l}\text { Ketut D } \\
\text { Rawarsa }\end{array}$ & 69 \\
\hline 3 & Kadek Putri & 76 \\
\hline
\end{tabular}

\begin{tabular}{|c|c|c|}
\hline & Andriani & \\
\hline 4 & Ketut Widiada & 76 \\
\hline 5 & Luh Redini & 67 \\
\hline 6 & $\begin{array}{l}\text { Komang Febri } \\
\text { Swastika }\end{array}$ & 64 \\
\hline 7 & $\begin{array}{l}\text { Kadek Putri } \\
\text { Virdavanti }\end{array}$ & 55 \\
\hline 8 & $\begin{array}{ll}\text { Ketut } & \text { Redi } \\
\text { Saputra } & \\
\text { Tanaya } & \end{array}$ & 66 \\
\hline 9 & $\begin{array}{l}\text { Putu Juli } \\
\text { Artini }\end{array}$ & 68 \\
\hline 10 & $\begin{array}{l}\text { Komang } \\
\text { Somaada }\end{array}$ & 72 \\
\hline 11 & $\begin{array}{l}\text { Deva } \\
\text { Tamtama } \\
\text { Saputra }\end{array}$ & 72 \\
\hline 12 & $\begin{array}{l}\text { Ketut } \\
\text { Sukenadi }\end{array}$ & 58 \\
\hline 13 & $\begin{array}{l}\text { Komang } \\
\text { Penita } \\
\text { Purnama Sari }\end{array}$ & 69 \\
\hline 14 & $\begin{array}{l}\text { Kadek Krisna } \\
\text { Damayanti }\end{array}$ & 75 \\
\hline 15 & $\begin{array}{l}\text { Kadek Laksmi } \\
\text { Dewi }\end{array}$ & 77 \\
\hline 16 & $\begin{array}{l}\text { Made Widi } \\
\text { Adiningsih }\end{array}$ & 72 \\
\hline 17 & $\begin{array}{l}\text { Gusti Made } \\
\text { Sudiardana }\end{array}$ & 70 \\
\hline 18 & $\begin{array}{l}\text { Luh Jaya } \\
\text { Setuti }\end{array}$ & 74 \\
\hline 19 & $\begin{array}{l}\text { Made } \\
\text { Puriasih }\end{array}$ & 72 \\
\hline 20 & $\begin{array}{l}\text { Ketut Juni } \\
\text { Dastrawan }\end{array}$ & 78 \\
\hline 21 & $\begin{array}{l}\text { Komang Ayu } \\
\text { Marleniasih }\end{array}$ & 63 \\
\hline 22 & Komang Pipi & 70 \\
\hline 23 & $\begin{array}{l}\text { Komang Wira } \\
\text { Yudana }\end{array}$ & 63 \\
\hline 24 & $\begin{array}{l}\text { Kadek } \\
\text { Deselly }\end{array}$ & 71 \\
\hline 25 & $\begin{array}{l}\text { Komang } \\
\text { Sumajaya }\end{array}$ & 74 \\
\hline 26 & $\begin{array}{l}\text { Dewa Ayu } \\
\text { Diva Sundari }\end{array}$ & 72 \\
\hline 27 & $\begin{array}{l}\text { Gusti Kadek } \\
\text { Sukreni }\end{array}$ & 73 \\
\hline 28 & $\begin{array}{ll}\text { Luh } & \text { Nik } \\
\text { Sudiari } & \end{array}$ & 71 \\
\hline 29 & Komang & 72 \\
\hline
\end{tabular}




\begin{tabular}{|c|l|c|}
\hline & Sariasih & \\
\hline 30 & $\begin{array}{l}\text { Kadek Bima } \\
\text { Putra }\end{array}$ & 71 \\
\hline \multicolumn{2}{|l|}{ Total } & 2109 \\
\hline
\end{tabular}

Untuk memperoleh gambaran tentang karakteristik setiap variabel, maka digunakan analisis deskriptif. Analisis deskripif dilakukan untuk menjelaskan dan menggambarkan hasil pengolahan data. Data nilai siswa anggota KIR dan bukan anggota KIR dimasukkan dalam aplikasi SPSS, setelah data-data tersebut dimasukkan maka akan muncul hasil uji deskriptif data penelitian. Berikut ini disajikan deskripsi data yang meliputi mean, median, mode, standar deviasi, varian, range, minimun dan maksimum setiap variabel. Analisis tersebut dapat dilihat pada tabel 3 di bawah.

Tabel 3

Hasil Uji Deskriptif Data Penelitian

\begin{tabular}{|c|r|r|}
\hline \multicolumn{3}{|c|}{ Statistics } \\
\hline & \multicolumn{1}{|l|}{$\begin{array}{l}\text { Anggota } \\
\text { KIR }\end{array}$} & $\begin{array}{l}\text { Bukan } \\
\text { anggota } \\
\text { KIR }\end{array}$ \\
\hline Valid & 30 & 30 \\
\hline Missing & 0 & 0 \\
\hline Mean & 79.27 & 70.3 \\
& & 0 \\
\hline Median & 7 & 71.5 \\
& 8.50 & 0 \\
\hline Mode & 7 & 72 \\
\hline Std. & 8 & 5. \\
Deviation & 456 & 5.54 \\
\hline Variance & 1 & 30.7 \\
\hline Range & 9.857 & 00 \\
\hline Minimum & 1 & 24 \\
\hline Maximum & 8 & 5 \\
\hline Sum & 0 & 5 \\
\hline & 8 & 79 \\
\hline
\end{tabular}

Berdasarkan Tabel 3, nilai karya ilmiah yang dihasilkan oleh siswa anggota KIR dan yang bukan anggota KIR dengan jumlah masing-masing 30 orang, diperoleh nilai rata-rata karya ilmiah. Nilai rata-rata karya ilmiah yang dihasilkan oleh siswa anggota KIR 79,27, sedangkan nilai ratarata karya ilmiah yang dihasilkan oleh siswa bukan anggota KIR 70,30. Dengan demikian dapat disimpulkan bahwa nilai rata-rata karya ilmiah yang dihasilkan oleh siswa anggota KIR lebih besar dibandingkan dengan nilai rata-rata karya ilmiah yang dihasilkan oleh siswa bukan anggota KIR.

Dalam melakukan uji hipotesis, langkah awal yang harus dilakukan yaitu uji normalitas data. Uji normalitas data dilakukan dengan tujuan agar dapat memperoleh informasi mengenai distribusi kenormalan data. Selain itu, uji normalitas data juga akan menentukan langkah yang harus ditempuh selanjutnya, yaitu analisis statistik apa yang harus digunakan, apakah statistik parametrik atau non parametrik. Langkah yang dilakukan adalah dengan menginput dan menganalisis menggunakan deskripsi explore data pada menu SPSS. Dengan bantuan aplikasi SPSS 24.0 for Windows diperoleh hasil uji normalitas seperti pada tabel 4 berikut.

Tabel 4

Hasil Uji Normalitas Sebaran Data OneSample Kolmogorov-Smirnov Test

\begin{tabular}{|l|r|r|r|r|r|r|}
\hline \multicolumn{7}{|c|}{ Tests of Normality } \\
\hline & \multicolumn{2}{|c|}{ Kolmogorov-Smimov ${ }^{\mathrm{a}}$} & \multicolumn{3}{c|}{ Shapiro-Wilk } \\
\cline { 2 - 7 } & Statistic & Df & Sig. & Statistic & Df & Sig. \\
\hline Anggota KIR & .139 & 30 & .145 & .949 & 30 & .162 \\
\hline Bukan anggota & .150 & 30 & .082 & .932 & 30 & .056 \\
KIR & & & & & & \\
\hline a. Lilliefors Significance Correction & & & & & \\
\hline
\end{tabular}

Berdasarkan tabel 4 di atas, dapat dilihat nilai signifikan dari data kelas yang mengikuti kegiatan ekstrakurikuler KIR sebesar 0,145 lebih besar dari 0,05 $(0,145>0,05)$ dan nilai signifikan dari data kelas siswa yang tidak mengikuti kegiatan ekstrakurikuler KIR sebesar 0,082 yang artinya lebih besar dari $0,05(0,082>0,05)$. Hal ini memberikan kesimpulan bahwa data 
berasal dari populasi yang berdistribusi normal.

Setelah uji normalitas, langkah ke dua harus melakukan uji homogenitas. Tujuan uji homogenitas data adalah untuk mengetahui apakah data tersebut berasal dari sampel atau populasi yang homogen atau tidak. Selain itu juga untuk menentukan jenis statistik apa yang selanjutnya digunakan dalam uji hipotesis data, karena syarat dari uji statistik parametrik adalah data penelitian harus berdistribusi normal dan homogen. Uji ini juga dilakukan untuk melakukan langkah selanjutnya pada uji hipotesis. Uji Levene digunakan untuk melihat apakah data yang digunakan memiliki varians yang homogen. Dengan bantuan aplikasi SPSS 24.0 for Windows diperoleh hasil uji homogenitas varians seperti tabel 5 berikut.

\section{Tabel 5}

Rangkuman Hasil Uji Homogenitas Varians Test of Homogeneity of Variances

\begin{tabular}{|c|c|c|c|}
\hline & $\begin{array}{r}\text { ne's T } \\
\text { Va }\end{array}$ & $\begin{array}{l}\text { of Equ } \\
\operatorname{ces}^{a}\end{array}$ & rror \\
\hline $\mathrm{De}$ & dent V & le: D & \\
\hline $\mathrm{F}$ & $\mathrm{df1}$ & $\mathrm{df} 2$ & Siq. \\
\hline 855 & 1 & $\begin{array}{l}5 \\
8\end{array}$ & .359 \\
\hline $\begin{array}{r}\mathrm{Te} \\
\text { error var } \\
\text { equal ac }\end{array}$ & $\begin{array}{l}\text { the nul } \\
\text { ce of th } \\
\text { s grour }\end{array}$ & $\begin{array}{l}\text { thesi } \\
\text { sende }\end{array}$ & le is \\
\hline
\end{tabular}

Dari tabel Levene di atas dapat dilihat nilai signifikan sebesar 0,359 yang berarti lebih besar dari $0,05(0,359>0,05)$. Hal ini memberikan kesimpulan bahwa data berasal dari varians yang sama/homogen.

Dari uji normalitas dan homogenitas diketahui bahwa data berasal dari populasi yang berdistribusi normal dan variannya homogen. Maka dari itu, uji hipotesis dapat dilakukan. Uji hipotesis data dilakukan guna mendapatkan kesimpulan dari data yang diperoleh. Jenis analisis statistik yang digunakan untuk melakukan uji hipotesis dalam rangka mencari kesimpulan ditentukan oleh hasil uji normalitas dan homogenitas data. Dalam uji hipotesis ini penulis membandingkan hasil karya ilmiah siswa anggota KIR dengan hasil karya ilmiah siswa bukan anggota KIR. Pengujian ini dilakukan untuk mengetahui apakah ada pengaruh yang signifikan dari kegitan ekstrakurikuler Kelompok Ilmiah Remaja terhadap keterampilan menulis karya ilmiah siswa.

Uji hipotesis untuk mengetahui perbedaan antara dua kelompok sampel, digunakann analisis dengan independent sampel t-tes. Output yang dihasilkan setelah pengolahan, diperoleh uji-t (uji beda rata-rata). Hasil perhitungan uji $t$ satu ekor dapat dilihat pada Tabel 4.6.

Tabel 6 Rangkuman Hasil Uji T

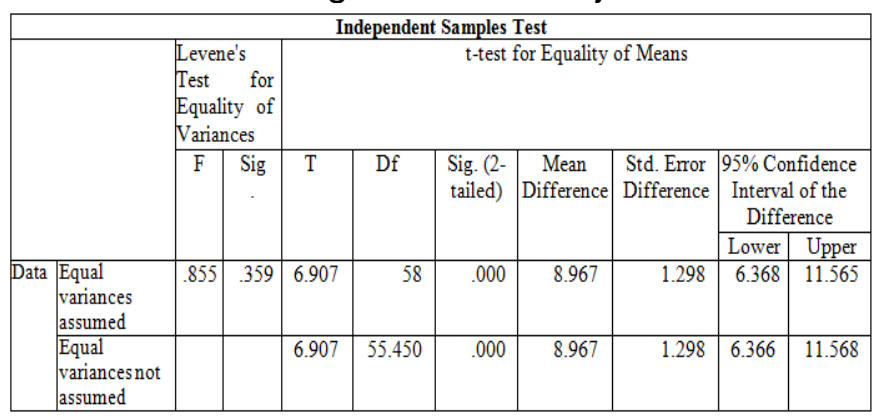

Dari perhitungan pada tabel kerja di atas, diperoleh $t_{\text {hitung }}=6,907$. Adapun nilai $t_{\text {tabel }}$ dengan taraf signifikan 0,05 dan derajat kebebasan $\mathrm{dk}=30+30-2=58$ adalah 2,001. Dengan demikian nilai $t_{\text {hitung }}>t_{\text {tabel }}(6,907>2,001)$ dan nilai signifikan $0,000<0,05$ yang berarti $H_{0}$ ditolak. Hal ini, dapat disimpulkan bahwa kegiatan ekstrakurikuler Kelompok IImiah Remaja berpengaruh terhadap keterampilan menulis karya ilmiah siswa kelas XI SMA Negeri 1 Sawan, serta hasil karya ilmiah siswa anggota KIR memiliki kualitas lebih baik dibandingkan dengan siswa bukan anggota KIR.

Kegiatan ekstrakulikuler KIR dapat memberikan pengaruh terhadap keterampilan menulis karya ilmiah siswa kelas XI SMA Negeri 1 Sawan. Hal ini sesuai dengan data yang didapatkan bahwa, nilai rata-rata karya ilmiah yang dihasilkan oleh siswa anggota KIR 79,27 
sedangkan nilai rata-rata karya ilmiah yang dihasilkan oleh siswa bukan anggota KIR 70,30 dengan jumlah masing-masing 30 orang. Dari perhitungan data pada tabel 4.6, diperoleh $t_{\text {hitung }}=6,907$. Adapun nilai $t_{\text {tabel }}$ dengan taraf signifikan 0,05 dan derajat kebebasan $\mathrm{dk}=30+30-2=58$ adalah 2,001. Dengan demikian nilai $t_{\text {hitung }}>t_{\text {tabel }}(6,907>2,001)$ dan nilai signifikan $0,000<0,05$ yang berarti $H_{0}$ ditolak. Oleh karena itu, dapat disimpulkan rata-rata nilai karya ilmiah yang dihasilkan oleh siswa anggota KIR lebih besar dibandingkan dengan rata-rata nilai karya ilmiah yang dihasilkan oleh siswa bukan anggota KIR, serta dari perhitungan tabel 4.6 sudah jelas bahwa kegiatan ekstrakurikuler KIR berpengaruh terhadap keterampilan menulis karya ilmiah siswa kelas XI SMA Negeri 1 Sawan. Jadi, kegiatan ekstrakurikuler KIR memberikan pengaruh positif terhadap keterampilan menulis karya ilmiah siswa.

Hal tersebut juga didukung oleh penelitian yang dilakukan oleh Pungky Septiriani pada tahun 2017 yaitu Pertama, siswa anggota KIR memiliki rata-rata skor kualitas kegiatan esktrakurikuler KIR dengan klasifikasi cukup (skor 1,38). Ratarata terendah (skor 0) ditunjukkan oleh siswa dengan kualitas kurang, rata-rata tertinggi (skor 3) ditunjukkan oleh siswa dengan kualitas baik. Berdasarkan keterampilan menulis karya ilmiah, siswa berkualitas cukup menunjukkan persentase paling rendah 49,26\% daripada keterampilan menulis karya ilmiah siswa dengan kualitas kurang 54,7\%, dan keterampilan menulis karya ilmiah siswa dengan kualitas baik 60,82\%. Dengan demikian dapat dinyatakan bahwa kegiatan ekstrakurikuler berpengaruh terhadap kemampuan menulis karya ilmiah.

Kemampuan menulis merupakan suatu hal yang penting dalam pembelajaran bahasa Indonesia maupun dalam kegiatan ekstrakurikuler KIR. Menulis seperti halnya kegiatan berbahasa lainnya, merupakan keterampilan. Setiap keterampilan hanya akan diperoleh melalui berlatih. Berlatih secara sistematis, terus-menerus, dan penuh disipilin merupakan resep yang selalu disarankan oleh praktisi untuk dapat atau terampil menulis. Tentu saja bekal untuk berlatih bukan hanya sekadar kemauan, melainkan juga ada bekal lain yang perlu dimiliki. Bekal lain itu adalah pengetahuan, konsep, prinsip, dan prosedur yang harus ditempuh dalam kegiatan menulis. Darmadi (dalam Wicaksono, 2014:2) mengungkapkan bahwa kemampuan menulis didapatkan bukan melalui warisan, tetapi melalui proses belajar. Proses belajar didaptkan siswa bukan hanya sekadar di dalam kelas pada saat kegiatan pembelajaran, proses belajar juga bisa didapatkan di luar kelas atau di luar jam pelajaran. Proses belajar yang didapatkan di luar kelas yaitu bisa didapatkan melalui kegiatan ektrakurikuler KIR. Dalam kegiatan ekstrakurikuler KIR siswa akan diberikan tambahan ilmu pengetahuan mengenai menulis, khususnya menulis karya ilmiah. Oleh karena itu, siswa yang mengikuti kegiatan ekstrakurikuler KIR akan mendapatkan pengetahuan lebih mengenai menulis karya ilmiah dibandingkan dengan siswa yang tidak mengikuti ekstrakurikuler KIR. Hasil tulisan atau hasil karya ilmiah siswa yang mengikuti ekstrakurikuler KIR akan lebih baik dibandingkan dengan siswa yang tidak mengikuti kegiatan ekstrakurikuler KIR.

Siswa yang mengikuti kegiatan ektrakurikuler KIR mendapatkan tambahan pengetahuan menulis karya ilmiah dari pembina KIR, sehingga ilmu yang didapatkan lebih banyak dibandingkan dengan siswa yang tidak mengikuti ekstrakurikuler KIR. Selain itu, siswa yang mengikuti kegiatan ekstrakurikuler KIR lebih banyak mendapatkan latihan menulis karya ilmiah dibandingkan dengan siswa yang tidak mengikuti kegiatan ekstrakurikuler $\mathrm{KIR}$, karena sesungguhnya menulis merupakan suatu kebiasaan. Semakin sering menulis maka hasil tulisan akan semakin baik dan sistematis, serta cara berpikir juga akan semakin bagus. Hal tersebut sejalan dengan pendapat Wicaksono (2014:3) bahwa semakin sering menulis, semakin besar pula kemampuan seseorang dalam membuat tulisan. Hal senada juga diungkakan Tarigan (dalam 
wicaksono, 2014:3) bahwa menulis merupakan alat komunikasi secara tidak langsung, dan kemampuan ini dapat diperoleh dengan cara praktik yang teratur. Oleh sebab itu, kegiatan ekstrakurikuler KIR berpengaruh terhadap keterampilan menulis karya ilmiah siswa, karena siswa anggota KIR memiliki waktu lebih banyak untuk berlatih menulis dibandingkan dengan siswa bukan anggota KIR yang hanya menulis saat pembelajaran di dalam kelas saja.

Di SMA Negeri 1 Sawan keterampilan menulis karya ilmiah bisa didapatkan di dalam kelas yang merupakan bagian kecil dari pembelajaran bahasa Indonesia pada Standar Kompetensi (SK) aspek keterampilan menulis dan di luar kelas yaitu pada kegiatan eksrtakurikuler KIR. Siswa yang mengikuti kegiatan ekstrakurikuler $\mathrm{KIR}$, pengetahuan mengenai menulis karya ilmiah akan lebih banyak. Untuk memperoleh keterampilan menulis lebih baik tentu yang harus dilakukan adalah banyak berlatih, namun seorang penulis harus memiliki kemampuan dalam menulis. Kemampuan menulis sangat membantu dalam mengkomunikasikan ide dan gagasan dalam tulisan. Kemampuan menulis akan bertambah ketika banyak berlatih. Latihan menulis tidak cukup hanya dilakukan pada saat proses pembelajaran di kelas saja, melainkan harus ada tambahan berlatih di luar jam pelajaran seperti pada ekstrakurikuler KIR. Hakim (2009:253) mengungkapkan menulis adalah keterampilan atau skill. Keterampilan atau skill, membutuhkan "jam terbang" untuk mencapai kualitas tertentu, semakin sering menulis, maka akan semakin meningkatlah kemampuan orang dalam membuat suatu tulisan. Oleh karena itu, untuk mendapatkan kualitas tulisan yang baik diperlukan latihan menulis lebih banyak.

Karya ilmiah yang dihasilkan oleh siswa anggota KIR kualitasnya lebih baik dibandingkan dengan karya ilmiah siswa yang dihasilkan oleh siswa bukan anggota KIR. Siswa anggota KIR selain mendapat pengetahuan dan latihan di dalam proses pembelajaran di kelas, mereka juga mendapatkan pengetahuan dan latihan dalam kegiatan ekstrakurikuler KIR. Oleh
Karena itu, ilmu yang mereka dapatkan lebih banyak dari siswa yang bukan anggota KIR. Hal ini bisa dilihat dari data yang sudah didaptkan oleh peneliti pada tabel 1 dan 2. Pada tabel tersebut sudah terlihat jelas nilai karya ilmiah siswa anggota KIR tidak ada di bawah 70, karena nilai minimumnya adalah 70 dan nilai maksimumnya adalah 88. Sedangkan siswa yang bukan anggota KIR masih banyak yang mendapatkan nilai di bawah 70 , nilai minimum pada siswa bukan anggota KIR adalah 55, dan nilai maksimumnya 79. Rata-rata yang dihasilkan oleh siswa anggota KIR 79,27 sedangkan rata-rata nilai karya ilmiah yang dihasilkan oleh bukan anggota KIR 70,30. Dari pemerolehan nilai tersebut sudah sangat jelas bahwa kualitas penulisan karya ilmiah siswa anggota KIR lebih baik dibandingkan dengan siswa bukan anggota KIR.

Pemaparan tersebut didukung oleh penelitian yang dilakukan oleh Pungky Septiriani pada tahun 2017 dengan judul "Korelasi Kegiatan Ekstrakurikuler Kelompok IImiah Remaja (KIR) dengan Kemampuan Literasi Informasi Siswa SMA Negeri 2 Malang". Penelitian tersebut menggunakan rancangan penelitian korelasional dengan menggunakan pendekatan kuantitatif. Adapun hasil penelitian yang diperoleh yaitu terdapat hubungan antara kegiatan ekstrakurikuler KIR dengan kemampuan literasi informasi siswa SMA Negeri 2 Malang. Hasil perhitungan statistik menunjukkan koefisein korelasi sebesar 0,101 dan nilai signifikansi sebesar 0,709. Sehingga dapat dinyatakan bahwa karya ilmiah yang dibuat oleh siswa yang mengikuti ekstrakurikuler KIR lebih baik dibandingkan siswa yang tidak mengikuti ekstrakurikuler KIR.

\section{SIMPULAN DAN SARAN}

Ada beberapa simpulan yang dapat diambil berdasarkan hasil dan pembahasan penelitian yaitu. 1) Kegiatan ekstrakurikuler KIR memberikan pengaruh positf terhadap kualitas karya ilmiah. Hal tersebut ditunjukkan dengan karya ilmiah yang dihasilkan oleh siswa anggota KIR dan yang bukan anggota KIR dengan jumlah 
masing-masing 30 orang diperoleh rata-rata nilai karya ilmiah yang dihasilkan oleh siswa anggota KIR 79,27 sedangkan rata-rata nilai karya ilmiah yang dihasilkan oleh bukan anggota KIR 70,30, serta nilai $t_{\text {hitung }}>t_{\text {tabel }}(6,907>2,001)$ dan nilai signifikan $0,000<0,05$ yang berarti $H_{0}$ ditolak. Maka dari itu, dapat disimpulkan bahwa kegiatan ekstrakurikuler Kelompok Ilmiah Remaja berpengaruh terhadap keterampilan menulis karya ilmiah siswa kelas XI SMA Negeri 1 Sawan. 2) Kualitas karya ilmiah yang dihasilkan oleh siswa anggota KIR lebih baik dibandingkan dengan kualitas karya ilmiah yang dihasilkan oleh siswa bukan anggota KIR. $\mathrm{Hal}$ ini dapat dilihat dari nilai minimal yang dihasilkan oleh siswa anggota KIR adalah 70 dan nilai maksimalnya adalah 88, sedangkan nilai minimal yang dihasilkan oleh siswa bukan anggota KIR adalah 55 dan nilai maksimalnya adalah 79 . Dari nilai tersebut sudah sangat jelas bahwa kualitas karya ilmiah yang dihasilkan oleh siswa anggota KIR lebih baik dibandingkan dengan karya ilmiah yang dihasilkan oleh siswa bukan anggota KIR.

Berdasarkan pemaparan mengenai hasil dan pembahasan penelitian serta simpulan, ada tiga saran yang dapat peneliti sampaikan dalam penelitian ini. Pertama bagi siswa, hasil penelitian ini siswa diharapkan lebih mudah termotivasi untuk menngikuti kegiatan ekstrakurikuler KIR, karena dengan mengikuti ekstrakurikuler KIR siswa akan mendapatkan pengetahuan lebih mengenai menulis karya ilmiah sehingga akan lebih mudah memahami materi pelajaran keterampilan menulis khususnya menulis karya ilmiah. Kedua bagi guru, hasil penelitian ini guru di SMA Negeri 1 Sawan diharapkan mampu mendorong motivasi siswa untuk mengikuti kegiatan ekstrakurikuler KIR. Terutama bagi guru bahasa Indonesia, karena dari kegiatan ekstrakurikuler KIR akan membantu siswa untuk mendapatkan pengetahuan lebih dan membiasakan diri untuk menulis. Ketiga bagi sekolah, hasil penelitian ini diharapkan kepada kepala sekolah SMA Negeri 1 Sawan mampu menggunakan sebagai bahan dasar untuk meningkatkan penulisan karya ilmiah siswa melalui kegiatan ekstrakurikuler KIR.

\section{DAFTAR PUSTAKA}

Anwar, Sudirman. 2015. Management of Student Development. Riau: Yayasan Indragiri.

Gunawan, Imam. 2015. Metode Penelitian Kualitatif: Teori dan Praktik. Jakarta: Bumi Aksara.

Hakim , Chappy. 2009. Cat Rambut Orang Yahudi. Jakarta: Kompas

Keraf, Gorys. 2007. Argumentasi dan Narasi. Jakarta: PT Gramedia Pustaka.

Suandi, I Nengah, dkk. 2013. Keterampilan Berbahasa Indonesia (Berorientasi Integrasi Nasional dan Harmoni Sosial). Singaraja: Universitas Pendidikan Ganesha.

Septriani, Pungky. 2017. Korelasi Kegiatan Ekstrakurikuler Kelompok IImiah Remaja (KIR) dengan Kemampuan Literasi Informasi Siswa SMA 2 Malang. Malang: Universitas Malang.

Susilowarno, Remigius Gunawan. 2003. Kelompok Ilmiah Remaja. Jakarta: PT Gasindo.

Wendra, I Wayan. 2016. Penulisan Karya Ilmiah (Buku Ajar). Singaraja: Universitas Pendidikan Ganesha.

Wicaksono, Andri. 2014. Menulis Kreatif Sastra dan Beberapa Model Pembelajarannya. Yogyakarta: Garudhawaca 